\title{
Fetal microtia and FGFR2 polymorphism
}

\author{
RUILIAN ZHAO ${ }^{1}$, PEIXIA DU ${ }^{2}$, HONGMEI SUN ${ }^{2}$, LI YANG $^{1}$ and PINGZHEN LIN ${ }^{1}$ \\ ${ }^{1}$ Department of Obstetrics and Gynecology, Maternity and Child Health Care of Zaozhuang, \\ Zaozhuang, Shandong 277100; ${ }^{2}$ Department of Obstetrics and Gynecology, \\ Shanting People's Hospital of Zaozhuang, Zaozhuang, Shandong 277200, P.R. China
}

Received December 4, 2018; Accepted April 12, 2019

DOI: $10.3892 /$ etm.2019.7568

\begin{abstract}
Association of the single-nucleotide polymorphism (SNP) of rs3135718 site in fibroblast growth factor receptor 2 (FGFR2) gene with congenital microtia was investigated. A total of 193 patients with congenital microtia (observation group) and 150 normal and healthy fetuses (control group) treated in Maternity and Child Health Care of Zaozhuang from January 2010 to October 2017 were randomly selected. The gene and genotype of the rs3135718 site of FGFR2 gene SNP were detected via quantitative polymerase chain reaction (qPCR). The association between rs3135718 site SNP and congenital microtia was analyzed. No statistically significant difference in the prevalence of congenital microtia was observed in the rs3135718 genotype (AG) between the observation and control group $(\mathrm{P}>0.05)$. The $\mathrm{GG}$ and $\mathrm{G}$ genotypes in rs3135718 were closely related to fetal microtia $(\mathrm{P}<0.05)$. Results revealed that the rs3135718-GG mutation was more correlated with the risk of microtia in male $(\mathrm{P}<0.05)$, but not correlated with the risk of microtia in female $(\mathrm{P}>0.05)$. Moreover, there was a statistically significant difference in the distribution of rs3135718-G allele frequency in male between the two groups $(\mathrm{P}<0.05)$. The rs3135718-G gene in FGFR2 has a certain association with the incidence of congenital microtia with high prevalence and risk.
\end{abstract}

\section{Introduction}

The number of malformed fetuses further increases with the ever-changing living conditions, which significantly affects the family well-being and national population. Fetal abnormality is referred to as developmental defects in fetal intelligence development, morphology and physiology attributable to various adverse factors in the course of fetal growth and development (1). Among all abnormalities, the congenital microtia, a common facial defect with an incidence

Correspondence to: Dr Pingzhen Lin, Department of Obstetrics and Gynecology, Maternity and Child Health Care of Zaozhuang, 25 Wenhua East Road, Zaozhuang, Shandong 277100, P.R. China E-mail: yanj9887@126.com

Key words: microtia, fibroblast growth factor 2 gene, correlation of $5 / 10,000$, is early detected during the prenatal examination, which is crucial for ensuring fetal quality. The chromosome 10q26 of fibroblast growth factor receptor 2 (FGFR2) gene, which primarily encodes tyrosine kinases, exerts a great effect on the cell growth and development as well as angiogenesis, and is involved in embryogenesis, especially in the process of cartilage and bone formation. Previous studies have demonstrated that the polymorphism of FGFR2 gene is bound up with the long bone mineral density of Chinese people, but there are no reports on the role of FGFR2 in bone formation and remodeling in adults $(2,3)$. Therefore, this study places emphasis on exploring the association of the single-nucleotide polymorphism (SNP) of rs3135718 site in FGFR2 gene with congenital microtia.

\section{Patients and methods}

General data. A total of 193 patients treated in Maternity and Child Health Care of Zaozhuang (Zaozhuang, China) and meeting the diagnostic criteria for congenital microtia and diagnosed with the congenital microtia from January 2010 to October 2017 were randomly selected as observation group. Moreover, 150 normal healthy children with the same age from January 2010 to October 2017 were selected as the control group. There were 105 males and 88 females with an average age of $14.33 \pm 6.58$ years in observation group, and 87 males and 63 females with an average age of $13.75 \pm 7.51$ years in control group. The statistical difference between the two groups was in sex $(\mathrm{P}<0.05)$, but not in age $(\mathrm{P}>0.05)$.

The study was approved by the Ethics Committee of Maternity and Child Health Care of Zaozhuang. Patients who participated in this research had complete clinical data. The signed informed consents were obtained from the patients or the guardians.

Sample collection. After $2 \mathrm{ml}$ venous blood was collected from all subjects enrolled, it was anti-coagulated with ethylenediamine tetracetic acid, sub-packaged and stored at $-80^{\circ} \mathrm{C}$. The genomic deoxyribonucleic acid (DNA) was extracted using the TIANamp Genomic DNA kit (Tiangen Biotech Co., Ltd., Beijing, China) in accordance with the instructions of the kit, and stored in a refrigerator at $-20^{\circ} \mathrm{C}$ for standby application.

Quantitative polymerase chain reaction ( $q P C R$ ). The primers (synthesized by Shanghai Invitrogen Biotechnology Co., Ltd., 
Table I. Primer sequences.

\begin{tabular}{lll}
\hline SNP & Fragment amplification primers & \multicolumn{1}{c}{ Probe primers } \\
\hline Rs3135718 & F: 5'-CCTCCAACAGTTTAGCTTTC-3' & FAM-CAACCCAAGCATTTTTAA \\
& R: 5'-TGAGCAGAAGCAACGTGACC-3' & VIC-CAACCCGAGCATTTTTAA \\
\hline
\end{tabular}

F, forward; R, reverse.

Table II. Hardy-Weinberg equilibrium analysis of distribution of rs3135718 genotype in FGFR2 gene.

\begin{tabular}{|c|c|c|c|c|c|}
\hline Site & Genotype & Control group & Composition ratio $(\%)$ & $\chi^{2}$ value & P-value \\
\hline \multirow[t]{3}{*}{ FGFR2 rs3135718 } & $\mathrm{AA}$ & 78 & 52.0 & & \\
\hline & $\mathrm{AG}$ & 61 & 40.7 & 0.278 & 0.654 \\
\hline & GG & 11 & 7.33 & & \\
\hline
\end{tabular}
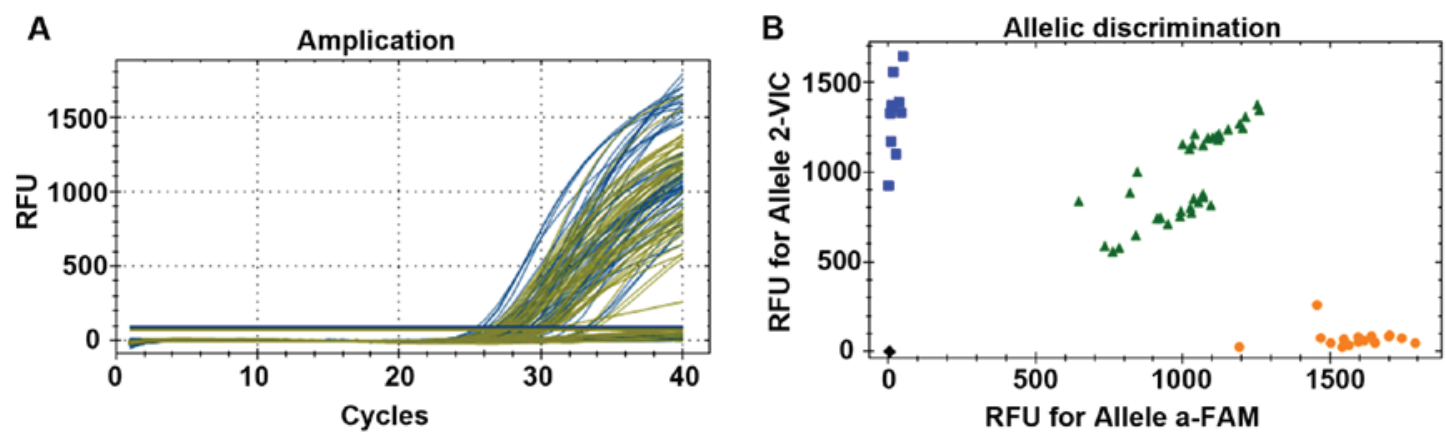

Figure 1. Results of rs3135718 typing in FGFR2 gene. (A) Amplification curve. (B) Results of genotyping.

Shanghai, China) were designed using the Primer Premier5.0 software according to the DNA sequences of human FGFR2 gene reported in the NCBI database, and the rs3135718 site in FGFR2 gene was typed via Taq-man PCR. The primer sequences are shown in Table I. The PCR system was $20 \mu \mathrm{l}$ in total: A total of $50 \mathrm{ng}$ genomic DNA, 1X PCR buffer, $3 \mathrm{mmol} / 1 \mathrm{MgCl}_{2}, 4 \mathrm{mmol} / \mathrm{ldNTPs}, 5 \mathrm{pmol} / \mathrm{l}$ primers and 1 unit TaqDNA polymerase (Qiagen, Inc., Valencia, CA, USA), and it was loaded on a CFX96 instrument for amplification (Bio-Rad Laboratories, Inc., Hercules, CA, USA). Parameters of qPCR amplification: $95^{\circ} \mathrm{C}$ for $30 \mathrm{sec}, 58^{\circ} \mathrm{C}$ for $30 \mathrm{sec}, 72^{\circ} \mathrm{C}$ for $30 \mathrm{sec}$, and then extension at $72^{\circ} \mathrm{C}$ for $7 \mathrm{~min}$ after 30 cycles. The experimental results were generated by the built-in software. Three repeated wells were set for each sample. The experimental results were analyzed using the $2^{-\Delta \Delta} \mathrm{Cq}$ method (4). The DEPC-treated water was used as the negative control, and the positive plasmid containing this sequence as the positive control (synthesized by Shanghai Sangon Biotech Co., Ltd., Shanghai, China).

Statistical analysis. The Hardy-Weinberg equilibrium test was performed for the genotype frequency of rs3135718 site in FGFR2 gene, and SPSS 20.0 (IBM Corp., Armonk, NY, USA) was used for processing. The difference in allele frequency between the observation and control group was analyzed using $\chi^{2}$ test. $\mathrm{P}<0.05$ was considered to indicate a statistically significant difference. The associations of rs3135718 polymorphism with the risk and clinicopathological parameters of congenital microtia were assessed via the unconditional logistic regression odds ratio (OR) and confidence interval (CI).

\section{Results}

Results of SNP genotyping. As shown in Fig. 1, a wild homozygous type (AA type) was near the FAM abscissa, a mutant homozygous type (GG type) was near the VIC ordinate, and a heterogeneous type (AG type) was near the $45^{\circ}$ line.

Hardy-Weinberg equilibrium analysis of distribution of rs3135718 genotype in FGFR2 gene. As shown in Table II, the distribution of gene and genotype frequency of rs3135718 site in FGFR2 gene in control group were consistent with the Hardy-Weinberg equilibrium, indicating that the subjects in this study were representative of the population $(\mathrm{P}>0.05)$.

Distribution of genotypes and their influences on congenital microtia. As shown in Table III, the influence of rs 3135718 genotype (AG) on the prevalence of congenital microtia had no statistically significant difference between the observation group and control group $(\mathrm{P}>0.05)$. 
Table III. Distribution of genotype and allele frequency of rs3135718 site [n (\%)].

\begin{tabular}{lcccccc}
\hline Genotype & $\begin{array}{c}\text { Observation group } \\
(\mathrm{n}=193)\end{array}$ & $\begin{array}{c}\text { Control group } \\
(\mathrm{n}=150)\end{array}$ & $\chi^{2}$ value & $\begin{array}{c}\text { OR } \\
(95 \% \mathrm{CI})\end{array}$ & $95 \%$ CI & P-value \\
\hline AA & $62(32.1)$ & $78(52)$ & 0.145 & 1.562 & $0.512-3.016$ & 0.012 \\
AG & $68(35.2)$ & $61(40.7)$ & 0.040 & 0.328 & $0.411-2.568$ & 0.850 \\
GG & $63(32.6)$ & $11(7.33)$ & 0.230 & 1.957 & $0.604-1.516$ & 0.050 \\
\hline
\end{tabular}

OR, odds ratio; CI, confidence interval.

Table IV. Correlation between genotypes and risk of fetal microtia,

\begin{tabular}{lccccc}
\hline SNP & Genotype & Crude OR (95\% CI) & P-value & Corrected OR (95\% CI) & P-value \\
\hline rs3135718 & AA & $0.943(0.749-1.186)$ & 0.614 & $0.987(0.783-1.243)$ & 0.910 \\
& GG & $0.630(0.434-0.914)$ & 0.015 & $0.725(0.497-1.057)$ & 0.095 \\
& AG & $0.652(0.461-0.923)$ & 0.016 & $0.731(0.514-1.039)$ & 0.180 \\
& A & $0.838(0.713-0.985)$ & 0.032 & $0.893(0.758-1.052)$ & 0.177 \\
& G & $0.723(0.686-0.875)$ & 0.052 & $0.783(0.652-1.112)$ & 0.065 \\
\hline
\end{tabular}

OR, odds ratio; CI, confidence interval.

Table V. Analysis of correlation between distribution of rs3135718 genotype frequency and risk of congenital microtia in the sexes.

\begin{tabular}{|c|c|c|c|c|c|c|c|c|}
\hline Site & Sex & Genotype & $\begin{array}{l}\text { Observation group } \\
\text { composition ratio }(\%)\end{array}$ & $\begin{array}{c}\text { Control group } \\
\text { composition ratio (\%) }\end{array}$ & $\chi^{2}$ value & P-value & OR & $95 \%$ CI \\
\hline \multirow[t]{12}{*}{ rs3135718 } & \multirow[t]{6}{*}{ Male } & \multirow[t]{2}{*}{ AA } & 54 & 44 & \multirow[t]{2}{*}{0.218} & \multirow[t]{2}{*}{0.756} & \multirow[t]{2}{*}{1.000} & \\
\hline & & & 51.43 & 50.57 & & & & \\
\hline & & \multirow[t]{2}{*}{ GG } & 43 & 28 & \multirow[t]{2}{*}{0.020} & \multirow[t]{2}{*}{0.025} & \multirow[t]{2}{*}{0.056} & \multirow[t]{2}{*}{$1.421-3.582$} \\
\hline & & & 40.95 & 26.7 & & & & \\
\hline & & \multirow[t]{2}{*}{$\mathrm{AG}$} & 6 & 4 & \multirow[t]{2}{*}{0} & \multirow[t]{2}{*}{0.956} & \multirow[t]{2}{*}{1.312} & \multirow[t]{2}{*}{$0.451-4.238$} \\
\hline & & & 4.8 & 4.41 & & & & \\
\hline & \multirow[t]{6}{*}{ Female } & \multirow[t]{2}{*}{ AA } & 50 & 34 & \multirow[t]{2}{*}{0.059} & \multirow[t]{2}{*}{0.952} & \multirow[t]{2}{*}{1.000} & \\
\hline & & & 56.8 & 53.97 & & & & \\
\hline & & \multirow[t]{2}{*}{ GG } & 31 & 23 & \multirow[t]{2}{*}{0.040} & \multirow[t]{2}{*}{0.85} & \multirow[t]{2}{*}{0.924} & \multirow[t]{2}{*}{$0.401-2.128$} \\
\hline & & & 35.22 & 36.51 & & & & \\
\hline & & \multirow[t]{2}{*}{$\mathrm{AG}$} & 6 & 5 & \multirow[t]{2}{*}{0} & \multirow[t]{2}{*}{1.00} & \multirow[t]{2}{*}{0.85} & \multirow[t]{2}{*}{$0.185-3.901$} \\
\hline & & & 6.82 & 7.94 & & & & \\
\hline
\end{tabular}

OR, odds ratio; CI, confidence interval.

Logistic regression analysis of association between genotypes and risk of fetal microtia. The GG and G genotypes in rs3135718 were closely related to fetal microtia $(\mathrm{P}<0.05)$ (Table IV).

Analysis of association between distribution of rs3135718 genotype frequency and risk of congenital microtia in the sexes. The results revealed that the mutation of $\mathrm{rs} 3135718-\mathrm{GG}$ site was more correlated with the risk of microtia in male $(\mathrm{P}<0.05)$, but not correlated with the risk of microtia in female
( $P>0.05)$, which could explain why the risk of microtia was higher in male to a certain extent (Table V).

Association between distribution of allele frequency and risk of microtia. The distribution of allele frequency in rs3135718 gene in observation group and control group was analyzed using $\chi^{2}$ test. The results confirmed that there was no statistically significant difference in the distribution of allele frequency in total population $(\mathrm{P}>0.05)$, while the difference in distribution of allele frequency of $\mathrm{rs} 3135718-\mathrm{G}$ in male 
Table VI. Correlation between distribution of allele frequency and risk of microtia.

\begin{tabular}{|c|c|c|c|c|c|c|c|c|}
\hline Site & Sex & Genotype & $\begin{array}{l}\text { Observation group } \\
\text { composition ratio }(\%)\end{array}$ & $\begin{array}{c}\text { Control group } \\
\text { composition ratio }(\%)\end{array}$ & $\chi^{2}$ & P-value & OR & $95 \%$ CI \\
\hline \multirow[t]{6}{*}{ rs3135718 } & General & A & $\begin{array}{l}130 \\
67.36\end{array}$ & $\begin{array}{l}139 \\
92.67\end{array}$ & 0.006 & 0.936 & 1.000 & - \\
\hline & & $\mathrm{G}$ & $\begin{array}{l}131 \\
67.88\end{array}$ & $\begin{array}{l}72 \\
61.07\end{array}$ & & & 0.0486 & $1.682-2.451$ \\
\hline & Male & A & $\begin{array}{l}60 \\
31.09\end{array}$ & $\begin{array}{l}48 \\
32\end{array}$ & 0.000 & 0.993 & 1.000 & - \\
\hline & & G & $\begin{array}{l}49 \\
25.39\end{array}$ & $\begin{array}{l}32 \\
21.3\end{array}$ & & & 0.038 & $1.653-2.649$ \\
\hline & Female & A & $\begin{array}{l}56 \\
29.02\end{array}$ & $\begin{array}{l}39 \\
26\end{array}$ & 0.068 & 0.795 & 1.000 & - \\
\hline & & $\mathrm{G}$ & $\begin{array}{l}37 \\
19.17\end{array}$ & $\begin{array}{l}28 \\
18.67\end{array}$ & & & 0.858 & $0.487-1.734$ \\
\hline
\end{tabular}

OR, odds ratio; CI, confidence interval.

between the two groups was statistically significant $(\mathrm{P}<0.05)$ (Table VI).

\section{Discussion}

Microtia is one of the most common manifestations of facial deformity with a high incidence $(4,5)$. It was reported that the prevalence of neonatal microtia is $0.84-17.5 / 10,000$ in the world and 3.79/10,000 in Australia, and it is higher in South America $(3.2 / 10,000)$ than that in other regions $(6,7)$. However, its etiology is still unclear. It is currently believed that scuh a congenital defect is largely attributable to both genetic and environmental factors $(8,9)$. The congenital microtia is primarily characterized by the abnormalities in external and middle ears, conductive or mixed deafness, mostly accompanied by preauricular pit, preauricular tag or accessory auricles, and some patients may also suffer from cleft palate, facial nerve dysplasia and facial asymmetry $(10,11)$. The SNP may be one of the original causes of congenital deformity. Guizar-Vázquez et al first discovered patients with familial aggregation microtia in the 1870s (12). Additionally, numerous studies have proposed that microtia is an autosomal dominant genetic disorder $(13,14)$. Along with the advancement of technology and the development of the times, the DNA detection has been one of the essential means to diagnose autosomal dominant genetic disorder. SNP is the most abundant form of DNA variation in human genome $(15,16)$. FGFRs, which belong to the family of receptor tyrosine protein kinases and contain at least 22 exons, act primarily by binding between their receptors and fibroblast growth factors $(17,18)$. Genetic studies have found that FGFR plays a vital role in the growth and development of bone and cartilage $(19,20)$. This study was designed to investigate the association of rs 3135718 site in FGFR2 gene SNP with congenital microtia.

In this study, the association between the polymorphism of rs3135718 gene in FGFRs and congenital microtia was investigated for the first time, and the genotype frequency distribution in the sexes and the association of the distribution of allele frequency with the risk of microtia were analyzed. The data analysis indicated that the distribution of genotypes was in line with the H-W equilibrium law, and the distribution of genotype frequency of rs3135718 polymorphism site in FGFRs in observation group and control group was statistically significant. Further stratification analysis in the sexes revealed that the polymorphism of rs3135718-G gene in FGFRs was related to the occurrence of congenital microtia. Due to a quite complicated etiology of congenital microtia and limited sample size in this experiment, the study results need further confirmation.

The influence of rs3135718 genotype (AG) on the prevalence of congenital microtia had no statistically significant difference between the observation group and control group $(\mathrm{P}>0.05)$. The $\mathrm{GG}$ and $\mathrm{G}$ genotypes in rs3135718 were closely related to fetal microtia $(\mathrm{P}<0.05)$. The results revealed that the rs3135718-GG mutation was more correlated with the risk of microtia in male $(\mathrm{P}<0.05)$, but not correlated with the risk of microtia in female $(\mathrm{P}>0.05)$. Moreover, there was a statistically significant difference in the distribution of rs3135718-G allele frequency in male between the groups $(\mathrm{P}<0.05)$, which accounted for the high incidence of congenital microtia in male patients.

In conclusion, the rs3135718-G gene in FGFR2 has a certain association with the incidence of fetal microtia with high prevalence and risk.

\section{Acknowledgements}

Not applicable.

\section{Funding}

No funding was received. 


\section{Availability of data and materials}

The datasets used and/or analyzed during the current study are available from the corresponding author on reasonable request.

\section{Authors' contributions}

RZ wrote the manuscript. PD helped with sample collection. RZ and HS performed qPCR. LY and PL contributed to statistical analysis. All authors read and approved the final manuscript.

\section{Ethics approval and consent to participate}

The study was approved by the Ethics Committee of Maternity and Child Health Care of Zaozhuang (Zaozhuang, China). Patients who participated in this research had complete clinical data. The signed informed consents were obtained from the patients or the guardians.

\section{Patient consent for publication}

Not applicable.

\section{Competing interests}

The authors declare that they have no competing interests.

\section{References}

1. Fischer S, Hirsch T, Hirche C, Kiefer J, Kueckelhaus M, Germann G and Reichenberger MA: Surgical treatment of primary gynecomastia in children and adolescents. Pediatr Surg Int 30: 641-647, 2014.

2. Yin L, Du X, Li C, Xu X, Chen Z, Su N, Zhao L, Qi H, Li F, Xue J, et al: A Pro253Arg mutation in fibroblast growth factor receptor 2 (Fgfr2) causes skeleton malformation mimicking human Apert syndrome by affecting both chondrogenesis and osteogenesis. Bone 42: 631-643, 2008.

3. Wang Y, Xiao R, Yang F, Karim BO, Iacovelli AJ, Cai J, Lerner CP Richtsmeier JT, Leszl JM, Hill CA, et al: Abnormalities in cartilage and bone development in the Apert syndrome FGFR2(+/S252W) mouse. Development 132: 3537-3548, 2005.

4. Livak KJ and Schmittgen TD: Analysis of relative gene expression data using real-time quantitative PCR and the 2 (-Delta Delta C(T)) method. Methods 25: 402-408, 2001.
5. Canfield MA, Langlois PH, Nguyen LM and Scheuerle AE: Epidemiologic features and clinical subgroups of anotia/microtia in Texas. Birth Defects Res A Clin Mol Teratol 85: 905-913, 2009.

6. Suutarla S, Rautio J, Ritvanen A, Ala-Mello S, Jero J and Klockars T: Microtia in Finland: Comparison of characteristics in different populations. Int J Pediatr Otorhinolaryngol 71: 1211-1217, 2007.

7. Forrester MB and Merz RD: Descriptive epidemiology of anotia and microtia, Hawaii, 1986-2002. Congenit Anom (Kyoto) 45: $119-124,2005$.

8. Harris J, Källén B and Robert E: The epidemiology of anotia and microtia. J Med Genet 33: 809-813, 1996.

9. Bartel-Friedrich S: Congenital auricular malformations: Description of anomalies and syndromes. Facial Plast Surg 31: 567-580, 2015.

10. Artunduaga MA, Quintanilla-Dieck ML, Greenway S, Betensky R, Nicolau Y, Hamdan U, Jarrin P, Osorno G, Brent B, Eavey R, et al: A classic twin study of external ear malformations, including microtia. N Engl J Med 361: 1216-1218, 2009.

11. Luquetti DV, Heike CL, Hing AV, Cunningham ML and Cox TC: Microtia: Epidemiology and genetics. Am J Med Genet A 158A: 124-139, 2012.

12. Guizar-Vázquez J, Arredondo-Vega F, Rostenberg I, Manzano C and Armendares S: Microtia and meatal atresia in mother and son. Clin Genet 14: 80-82, 1978.

13. Zankl M and Zang KD: Inheritance of microtia and aural atresia in a family with five affected members. Clin Genet 16: 331-334, 1979.

14. Orstavik KH, Medb $\varnothing$ S and Mair IW: Right-sided microtia and conductive hearing loss with variable expressivity in three generations. Clin Genet 38: 117-120, 1990.

15. Chafai Elalaoui S, Cherkaoui Jaouad I, Rifai L and Sefiani A: Autosomal dominant microtia. Eur J Med Genet 53: 100-103, 2010.

16. Konigsmark BW, Nager GT and Haskins HL: Recessive microtia, meatal atresia, and hearing loss. Report of a sibship. Arch Otolaryngol 96: 105-109, 1972.

17. Schmid M, Schröder M, Langenbeck U, Opitz JM and Reynolds JF: Familial microtia, meatal atresia, and conductive deafness in three siblings. Am J Med Genet 22: 327-332, 1985.

18. Strisciuglio P, Ballabio A and Parenti G: Microtia with meatal atresia and conductive deafness: Mild and severe manifestations within the same sibship. J Med Genet 23: 459-460, 1986.

19. Ornitz DM and Marie PJ: FGF signaling pathways in endochondral and intramembranous bone development and human genetic disease. Genes Dev 16: 1446-1465, 2002.

20. Su N, Sun Q, Li C, Lu X, Qi H, Chen S, Yang J, Du X, Zhao L, He Q, et al: Gain-of-function mutation in FGFR3 in mice leads to decreased bone mass by affecting both osteoblastogenesis and osteoclastogenesis. Hum Mol Genet 19: 1199-1210, 2010.

(i)(2) This work is licensed under a Creative Commons Attribution-NonCommercial-NoDerivatives 4.0 International (CC BY-NC-ND 4.0) License. 